\title{
AN EVALUATION OF CONTINUOUS, SELECTIVE ATTENTION, REASONING AND COLLISION TIME PREDICTION SKILLS IN SECURITY GUARDS
}

\author{
GÜVENLIK GÖREVLILERINDE SÜREKLI, SEÇiCi DIKKAT, MUHAKEME VE ÇARPIŞMA \\ ZAMANI TAHMIN BECERILERININ DEĞERLENDIRILMESI
}

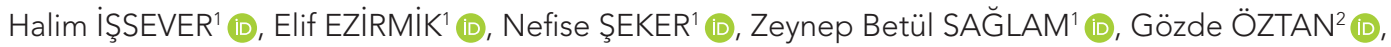 \\ Fatma CANATAR ${ }^{1}$ iD \\ ${ }^{1}$ Istanbul University, Istanbul Faculty of Medicine, Public Health Department, Istanbul, Turkey \\ ${ }^{2}$ Istanbul University, Istanbul Faculty of Medicine, Medical Biology, Istanbul, Turkey
}

ORCID IDs of the authors: H.I. 0000-0002-5435-706X; E.I. 0000-0001-6828-4378; N.Ş. 0000-0003-4722-3087;

Z.B.S. 0000-0001-9538-2969; G.Ö. 0000-0002-2970-1834; F.C. 0000-0001-6614-3862

Cite this article as: Issever H, Ezirmik E, Seker N, Saglam ZB, Oztan G, Canatar F. An evaluation of continuous, selective attention, reasoning and collision time prediction skills in security guards. J Ist Faculty Med 2021;84(4):582-9. doi: 10.26650/IUITFD.2021.864086

\begin{abstract}
Objective: This study aims at investigating the success of the continuous and selective attention, reasoning and collision prediction time test batteries which were among the tests used in the psychotechnical evaluation of security guards in meeting standard norms.
\end{abstract}

Materials and Methods: One hundred twenty-three security guards (95 male, 28 female) working as security guards at the university and agreeing to participate in the study were included in the study. Each participant was administered the Continuous Attention Test, Selective Attention Test (SEDT), Reasoning Test (MT), Collision Time Test on the computer-aided system, respectively, and the scores obtained were recorded on the computer-aided system. Licensed evaluation system software developed by ALG Psikoteknik (https://www.algpsikoteknik. com) was used as the test system. Norm values were created from the data collected from $100 \%$ Turkish society. Norm values are values for drivers in the computer-aided system.

Results: From the test batteries applied, 99 participants (80.5\%) in the continuous attention test, 117 participants (95.1\%) in the selective attention test, 111 participants $(90.2 \%)$ in the reasoning test and 73 participants (59.3\%) in the collision time prediction test were successful. In three of the 4 test batteries applied, over $80 \%$ success was achieved and almost $60 \%$ success was provided in the collision time prediction test.

\section{ÖZET}

Amaç: Bu çalışmada güvenlik görevlilerinde, psikoteknik değerlendirmede kullanılan testlerden sürekli ve seçici dikkat, muhakeme ve çarpışma zaman tahmin test bataryalarının standart normları karşılamada olan başarılarının araştırılması amaçlanmıştır.

Gereç ve Yöntemler: Üniversitede güvenlik görevlisi olarak çaIışan, çalışmaya katılmayı kabul eden 123 güvenlik görevlisi (95 erkek, 28 kadın) çalışma kapsamına dahil edildi. Her bir katılımcıya sırası ile bilgisayar destekli sistem üzerinde Sürekli Dikkat Testi (SÜDT), Seçici Dikkat Testi (SEDT), Muhakeme Testi (MT), Çarpışma Zamanı Testi uygulanarak alınan puanlar bilgisayar destekli sistem üzerinde kayıt edildi. Test sistemi olarak ALG psikoteknik (https://www.algpsikoteknik.com) tarafından geliştirilen lisanslı değerlendirme sistem yazılımı kullanıldı. Bilgisayar destekli sistemde norm değerleri, yüzde yüz Türk toplumundan toplanan verilerden oluşturulmuştur. Norm değerler sürücülere yönelik değerlerdir.

Bulgular: Uygulanan test bataryalarından; Sürekli dikkat testinde 99 katılımcı (\%80,5), Seçici dikkat testinde 117 katılımcı $(\% 95,1)$, Muhakeme testinde 111 katıımcı $(\% 90,2)$, Çarpışma zamanı tahmin testinde ise 73 katılımcı $(\% 59,3)$ başarılı olmuştur. Uygulanan 4 test bataryasının üç tanesinde; \%80'in üzerinde başarı, çarpışma zamanı tahmin testinde ise \%60'a yakın bir başarı elde edilmiştir.

Corresponding author/iletişim kurulacak yazar: hissever@istanbul.edu.tr

Submitted/Başvuru: 19.01.2021 • Revision Requested/Revizyon Talebi: 08.03.2021 •

Last Revision Received/Son Revizyon: 08.03.2021 • Accepted/Kabul: 08.03.2021 • Published Online/Online Yayın: 24.09 .2021 
Conclusion: Creating norm values specific to security guards and applying psychotechnical evaluation test batteries are beneficial in evaluating psychological situations.

Keywords: Security guards, psychotechnical evaluation, test batteries
Sonuç: Güvenlik görevlilerine özgü norm değerlerinin oluşturulması ve psikoteknik değerlendirme test bataryalarının uygulanması psikolojik durumların değerlendirilmesinde fayda sağlamaktadır.

Anahtar Kelimeler: Güvenlik görevlileri, psikoteknik değerlendirme, test bataryaları

\section{INTRODUCTION}

Private security has been one of the sectors that has developed significantly since the concept of the public service began to change in Turkey. The sector consists of many sub-sectors that provide services to meet various types of security needs of the society (1). Today the need for security is increasing in parallel with the increase in the quality and quantity of the assets that individuals possess. If properly used, the private security guards will effectively meet individual security needs, provide savings on security services, reduce the burden of overall security and lay the groundwork for more convenient and efficient work in their areas. The fragmentary and variable structure of modern society which is associated with the perception of danger and threat increases the need for security and makes police and other private security services more important (2).

However, security guards are exposed to violent attacks by citizens during their duties (3). Moreover, employees in these professions cannot withdraw from their working environment, even if they are under serious threat because they are called upon for help, and they also have a great responsibility to maintain law and order in society. Therefore, the problem-solving skills and personality traits of security guards become important when it comes to intervening in an incident $(4,5)$. The term "Problem" is defined as the obstacles that an individual faces at any stage to achieve the intended goal. The problem, which is expressed as an obstacle faced by the individual, has certain characteristics which cause uncertainty in the human mind, which must be solved and which bother that individual (6). The effective power available to overcome a wide range of issues from everyday life to traumatic incidents is defined as problem solving. The problem solving stage begins with cognitive processes aimed at a goal. Problem-solving skills mediate individuals' ability to adapt effectively to the environment in which they live. While some problems have correct answers or clear solutions, others do not. In this case, interdisciplinary knowledge and multifaceted thinking are important in solving problems (7). Different approaches to problem solving have been defined here according to the characteristics of the problem and the person interested in the problem.

The traditional approach involves identifying the problem, analysing its causes, identifying alternative solutions, evaluating and applying solutions, and determining whether the problem has been solved (8). In addition to the solution method, the continuous and selective attention, reasoning and reaction time of the security guard against the incidents also occupy an important place. Timely intervention in events will prevent the growth of negative consequences. If organizations make wrong choices in recruitment, there will be undesirable consequences including waste of resources for the organization and unhappiness at work for the staff. Choosing the right staff for the right job will make a positive contribution to the organization in terms of ensuring job satisfaction, using creativity and being successful (9). This study aimed to investigate the achievements of security guards in meeting standard norms by using continuous and selective attention, reasoning and collision time estimation tests batteries which are among the psychotechnical evaluation tests.

\section{MATERIALS AND METHODS}

One hundred twenty-three security guards (95 male, 28 female) working as security guards at the university and agreeing to participate in the study were included in the study. The success rate of the test of the participants was accepted as 0.60 and the minimum sample size (Type I error 0.05 , Type II error $0.20,0.80$ power) was calculated as 110 people with a $20 \%$ error margin. Tests, which were applied to the participants by means of a computeraided system installed in a quiet room, which was closed to external stimuli as shown by the university security supervisor, were explained in detail by Public Health Medical Specialty assistants and implemented after preliminary tests were carried out. After practitioners were trained by a specialist organization and entitled to receive a certificate of participation, the implementation phase was conducted. After answering 13 questions with regard to demographic features, each participant was administered the Continuous Attention Test, Selective Attention Test (SEDT), Reasoning Test (MT), Collision Time Test on the computer-aided system, respectively, and the scores obtained were recorded on the computer-aided system. Licensed evaluation system software developed by ALG Psikoteknik (https://www.algpsikoteknik.com) was used as the test system. Norm values were created from the data collected from $100 \%$ Turkish society. There are 12 test batteries in the system that measure mental and psychomotor skills. Four of the 12 test batteries were 
implemented with computer support that did not require a driver system. Ethical approval for the study was obtained from İstanbul University; İstanbul Faculty of Medicine; Clinical Research Ethics Committee (Date 19.08.2019, No: 1026). In statistical analysis, student's t-test and chi-square test were applied in independent groups. Statistical significance was accepted as $p<0.05$ and two-way.

\section{TESTS CONDUCTED}

\section{CONTINUOUS ATTENTION TEST}

\section{Definition of the test}

For this test, a specific traffic sign was selected as the target figure, and distractors were created that are quite similar to this sign. The target figure and the distractors were arranged in a matrix of $11 \times 17$. There are 50 target figures in this matrix consisting of a total of 186 distractors. The task of the participants is to quickly find and mark the same target shape at the top of the Matrix among the shapes in the Matrix. Attention in general means that among the many sets of internal and external stimulants, the critical one is selected for further analysis. In the working environment, they have to pay attention to many stimulants coming from different modalities such as visual or audio, to perceive them and to continue their safe behavior (10).

\section{Purpose of the test}

This test was developed to measure the ability of drivers to quickly and accurately identify and select a specific stimulant that is critical at the moment in the routine and monotonous flow of information so that they can demonstrate the necessary cognitive and motor skills in a traffic environment. It was also implemented to test the ability of security guards to quickly and accurately select a specific stimulant.

Overall Test Score Index: It is calculated by the formula [(Total Number of Correct Answers)/((Total Number of Skipped Responses) + (Total Number of Correct Answers) + (Total Number of Incorrect Answers) x100].

This index is a general score that shows the participant's level of continuous attention. The raw scores obtained by the participants from the test are compared with the norm values and evaluated to determine whether they received above the norm score.

\section{SELECTIVE ATTENTION TEST (SEDT)}

\section{Definition of the test}

Each question in this test consists of 6 traffic signs. Three of these signs are located on the upper row of a $3 \times 3$ Matrix, and 3 of them are located on the left side. Two of the traffic signs on the top and left are identical. The Test contains a total of 60 matrices. The participant must quickly find identical shapes, each located on the left and top of the Matrix, and show the intersection of these shapes by marking them on the screen with the index finger or a pen.

\section{Purpose of the test}

The traffic environment is a task that involves the selective attention of the driver in many cases so that he/she can demonstrate safe driving skills. For this reason, this test is aimed at evaluating the driver's ability to selectively pay attention to constantly changing environmental and road conditions so that they can demonstrate the necessary cognitive and motor skills in a traffic environment. In order to measure the selective attention of the driver in the test, an attempt is made to measure the ability to select similar ones from different stimulants and ignore others.

\section{Correct Answer Percentage (Overall Index): [(Total Number of Correct Answers/Total Number of Questions) x100]}

This index is a general score indicating the participant's selective attention level. The raw scores obtained by the participants from the test are compared with the norm values and evaluated to determine whether they received above the norm score.

\section{REASONING TEST (MT)}

\section{Definition of the test}

This test includes 50 multiple choice question items. The questions are sorted from easy to difficult. In each question, the participant is first asked to find the logical relationship between the two figures. Then, the participant must find and mark in which of the options another form of this relationship is presented. Each question has 4 options, and only one of them is the correct answer. The person has an answer time of 3 minutes for each question. The test is automatically terminated when the participant incorrectly answers or skips 2 questions in a row.

a) Colour: The change in the relationship between the two figures is based on color. In other words, the color of the first figure changes, resulting in the second figure.

b) Form: The change in the relationship between the two figures is based on the form. In other words, the form of the first figure changes, resulting in the second figure.

c) Quantity: The change in the relationship between the two figures is based on numbers. The second figure differs from the first figure in number or quantity.

d) Rotation: The change in the relationship between the two figures is based on rotation. The first figure or a part of the figure is rotated in various degrees, resulting in the second figure. When a participant gives an incorrect answer or skips a question twice in a row, the test automatically ends without moving on to other questions. 


\section{Purpose of the test}

The main purpose of this test is to measure one's general reasoning ability using nonverbal geometric shapes, regardless of culture. In the test, the participant's task is to find and determine the relationship between the two figures and then find the correct answer by determining the figure containing the same rule among the figures presented in four options. The main purpose of the test is to measure the reasoning ability through matching, regardless of culture and knowledge of mathematics or arithmetic.

Correct Answer Percentage (Overall Index): [(Total Number of Correct Answers/Total Number of Questions) x100]

This index is a general score indicating the participant's selective attention level. The raw scores obtained by the participant from the test are compared with the norm values and evaluated to determine whether they received above the norm score (10).

\section{COLLISION TIME TEST}

\section{Purpose of the test}

The participant is asked to estimate both the collision time and the collision location of the objects.

\section{Test features}

The moment (duration) at which objects actually collide with each other is considered the center, and the interval from the moment the balls disappear on the screen until the moment when a 77-pixel time was added to the moment when they collide is determined as the response area. Pursuant to the end of this area, the interval from the point of collision (different for each item) until the moment after $1786 \mathrm{~ms}$. is considered to be the late response area. If no response is given, it is passed to the next question when the balls arrive at the end of the late response area, and this question is considered to be skipped. The moment of collision, which is the center of the response area, is rated as "100" and the score decreases at a certain rate as you go from the center to the ends.

The extreme points of the response area and the late response area are " 0 " points. When calculating the location score, the sum of the distances of the point that the driver responds to for each question, in pixels, to the actual collision point, is divided by the number of questions that the driver responds to. Giving the response after 1056 pixels, which is the screen limit, causes the response to be considered skipped. After the driver specifies each prediction by tapping the screen, the time and location specified by the driver is automatically calculated. According to where this time and place coincide in the designated response area, the driver is given two separate scores for both time and location.
Security guards are asked to predict both the collision time and the collision location of objects oscillating in two directions on the computer screen.

\section{Evaluation of the results}

The following measurements are taken regarding the results of the test. The Collision Time Prediction Score (Overall Index) is the collision location distance score (Overall Index), the number of late responses and the number of skipped responses. The Collision Time Prediction Score (Overall Index) is a general score that indicates the time of collision. By comparing the raw scores of the participant from the test with the norm values, it is evaluated whether they get above the norm score (10).

\section{FINDINGS}

A total of 123 security guards were included in the study, 95 men (77.2\%) and 28 women (22.8\%) who worked as security guards at the university and agreed to participate in the study. Distribution of age, working year and total working year by gender is given in Table 1. The marital status, working style and educational status of the individuals covered by the study are given in Table 2 . According to the distribution of marital status, 34 were single (27.6\%), 89 were married $(72.4 \%), 107$ (87\%) were working in shifts, and the majority 105 (85.4\%) were high school graduates.

Table 1: Distribution of age, year of work and total years of work of individuals covered within the scope of the study by gender

\begin{tabular}{llccc}
\hline Gender & & Age & $\begin{array}{c}\text { Working } \\
\text { year }\end{array}$ & $\begin{array}{c}\text { Total } \\
\text { working year }\end{array}$ \\
\hline Male & Mean & 35.24 & 9.28 & 13.76 \\
& S. & & & \\
& Deviation & 4.71 & 3.57 & 5.70 \\
& Median & 35 & 10 & 14 \\
& Minimum & 24 & 2 & 3 \\
& Maximum & 49 & 16 & 33 \\
Female & Mean & 36.04 & 10.87 & 13.16 \\
& S. & & & \\
& Deviation & 5.35 & 3.02 & 4.73 \\
& Median & 34.5 & 10 & 13.25 \\
& Minimum & 28 & 3.5 & 3.5 \\
& Maximum & 48 & 16 & 26 \\
Total & Mean & 35.42 & 9.648 & 13.63 \\
& S. & & & \\
& Deviation & 4.8 & 3.51 & 5.48 \\
& Median & 35 & 10 & 14 \\
& Minimum & 24 & 2 & 3 \\
& Maximum & 49 & 16 & 33 \\
\hline
\end{tabular}


Table 2: Marital status, working style and educational status of individuals covered by the study

\begin{tabular}{lcc}
\hline Marital status & Number & Percentage \\
\hline Single & 34 & 27.6 \\
Married & 89 & 72.4 \\
Total & 123 & 100 \\
Working style & Number & Percentage \\
\hline Day & 16 & 13 \\
Shift & 107 & 87 \\
Total & 123 & 100 \\
Education status & Number & Percentage \\
\hline Secondary school & 6 & 4.9 \\
High school & 105 & 85.4 \\
University & 12 & 9.8 \\
Total & 123 & 100 \\
\hline
\end{tabular}

The success status of the individuals covered by the study in psychotechnical test batteries is given in Table 3. Among the test batteries applied, 99 participants (80.5\%) were successful in the Continuous Attention Test, 117 participants (95.1\%) in the Selective Attention Test, 111 participants (90.2\%) in Reasoning Test, and 73 participants (59.3\%) in the Collision Time Prediction Test. In three of the four test batteries applied, more than $80 \%$ success was achieved, and almost $60 \%$ success was achieved in

Table 3: Distribution of success status in psychotechnical test batteries of individuals covered by the study

\begin{tabular}{lcc}
\hline Continuous attention & Number & Percentage \\
\hline Adequate & 99 & $\mathbf{8 0 . 5}$ \\
Inadequate & 24 & 19.5 \\
Total & 123 & 100 \\
Selective attention & Number & Percentage \\
\hline Adequate & $\mathbf{1 1 7}$ & $\mathbf{9 5 . 1}$ \\
Inadequate & 6 & 4.9 \\
Total & 123 & 100 \\
Reasoning & Number & Percentage \\
\hline Adequate & $\mathbf{1 1 1}$ & $\mathbf{9 0 . 2}$ \\
Inadequate & 12 & 9.8 \\
Total & 123 & 100 \\
Collision time prediction & Number & Percentage \\
\hline Adequate & $\mathbf{7 3}$ & $\mathbf{5 9 . 3}$ \\
Inadequate & 50 & 40.7 \\
Total & 123 & 100 \\
\hline
\end{tabular}

the Collision Time Prediction Test. Distribution of test results by gender is given in Table 4 . The distribution of test results by gender was not found to be statistically significant. Distribution of test results by years of working is given in Table 5. The distribution of test results by years of working was not found to be statistically significant. Distribution of test results by education level is given in Table 6.

When the distributions of the applied tests according to the educational status of the participants were examined, only a statistically significant difference was found in the Reasoning Test $(p=0.002)$. Distributions were not found to be statistically significant in continuous, selective attention and collision time testing.

\section{DISCUSSION}

The Psychotechnical method is defined as a behavioural measurement method that has certain characteristics and is created with the help of tests collected within a special system (11). Individuals' compliance with the profession includes factors such as measuring their potential abilities and qualifications required for work, as well as the perception, reasoning, creativity and psychomotor abilities of employees, as well as the measurement of their physical and mental strength (12). Even though the psychotechnical assessments are usually at the forefront for drivers, they have begun to be performed as competency assessments for train drivers, forklift drivers, crane operators, security guards, production staff, pilots and many business lines including people involved in other public transport and critical tasks (13).

In our study, the Continuous Attention Test, Selective Attention Test (SEDT), Reasoning Test (MT), Collision Time Test were applied to the security guards of the university on the computer-aided system, and the scores obtained were recorded on the computer-aided system. Among the test batteries applied, 99 participants (80.5\%) were successful in the Continuous Attention Test, 117 participants (95.1\%) in the Selective Attention Test, 111 participants (90.2\%) in Reasoning Test, and 73 participants (59.3\%) in the Collision Time Prediction Test. In three of the four test batteries applied, more than $80 \%$ success was achieved, and almost $60 \%$ success was achieved in the Collision Time Prediction Test. When success scores were evaluated by gender and duration of working, no statistically significant differences were found in terms of gender and duration of work.

When the distributions of the applied tests according to the educational status of the participants were examined, only a statistically significant difference was found in the reasoning test. The number of participants achieving adequate results in high school and college educated people is significantly higher than secondary 
Table 4: Distribution of test results by gender

\begin{tabular}{|c|c|c|c|c|c|c|}
\hline & \multicolumn{3}{|c|}{ Gender } & \multirow[t]{2}{*}{ Total } & \multirow{2}{*}{$\frac{X^{2}}{0.695}$} & \multirow{2}{*}{$\frac{p}{0.404}$} \\
\hline & Continuous attention & Male & Female & & & \\
\hline \multirow[t]{2}{*}{ Adequate } & Number & 78 & 21 & 99 & & \\
\hline & Percent & 82.1 & 75.0 & 80.5 & & \\
\hline \multirow[t]{2}{*}{ Inadequate } & Number & 17 & 7 & 24 & & \\
\hline & Percent & 17.9 & 25.0 & 19.5 & & \\
\hline \multirow[t]{3}{*}{ Total } & Number & 95 & 28 & 123 & & \\
\hline & & \multicolumn{2}{|c|}{ Gender } & Total & & \\
\hline & Selective attention & Male & Female & & 0.401 & 0.527 \\
\hline \multirow[t]{2}{*}{ Adequate } & Number & 91 & 26 & 117 & & \\
\hline & Percent & 95.8 & 92.9 & 95.1 & & \\
\hline \multirow[t]{2}{*}{ Inadequate } & Number & 4 & 2 & 6 & & \\
\hline & Percent & 4.2 & 7.1 & 4.9 & & \\
\hline \multirow[t]{3}{*}{ Total } & Number & 95 & 28 & 123 & & \\
\hline & & \multicolumn{2}{|c|}{ Gender } & Total & & \\
\hline & Reasoning & Male & Female & & 0.038 & 0.846 \\
\hline \multirow[t]{2}{*}{ Adequate } & Number & 86 & 25 & 111 & & \\
\hline & Percent & 90.5 & 89.3 & 90.2 & & \\
\hline \multirow[t]{2}{*}{ Inadequate } & Number & 9 & 3 & 12 & & \\
\hline & Percent & 9.5 & 10.7 & 9.8 & & \\
\hline \multirow[t]{3}{*}{ Total } & Number & 95 & 28 & 123 & & \\
\hline & & \multicolumn{2}{|c|}{ Gender } & Total & & \\
\hline & Collision time & Male & Female & & 1.314 & 0.252 \\
\hline \multirow[t]{2}{*}{ Adequate } & Number & 59 & 14 & 73 & & \\
\hline & Percent & 62.1 & 50.0 & 59.3 & & \\
\hline \multirow[t]{2}{*}{ Inadequate } & Number & 36 & 14 & 50 & & \\
\hline & Percent & 37.9 & 50.0 & 40.7 & & \\
\hline Total & Number & 95 & 28 & 123 & & \\
\hline
\end{tabular}

Table 5: Distribution of test results by working year

\begin{tabular}{|c|c|c|c|c|c|c|c|}
\hline \multirow{2}{*}{ Continuous attention } & \multicolumn{7}{|c|}{ Working years } \\
\hline & Mean & S. Deviation & Median & Minimum & Maximum & $t$ & $p$ \\
\hline Inadequate & 10.54 & 3.36 & 11 & 3 & 16 & 1.398 & 0.165 \\
\hline Adequate & 9.43 & 3.53 & 10 & 2 & 16 & & \\
\hline Selective attention & Mean & S. Deviation & Median & Minimum & Maximum & & \\
\hline Inadequate & 11.83 & 2.86 & 12 & 8 & 15 & 1.574 & 0.118 \\
\hline Adequate & 9.53 & 3.51 & 10 & 2 & 16 & & \\
\hline Reasoning & Mean & S. Deviation & Median & Minimum & Maximum & & \\
\hline Inadequate & 10.17 & 2.29 & 9.5 & 7 & 14 & 0.538 & 0.592 \\
\hline Adequate & 9.59 & 3.62 & 10 & 2 & 16 & & \\
\hline Collision time test & Mean & S. Deviation & Median & Minimum & Maximum & & \\
\hline Inadequate & 9.81 & 3.19 & 10 & 3 & 14 & 0.407 & 0.684 \\
\hline Adequate & 9.54 & 3.73 & 10 & 2 & 16 & & \\
\hline
\end{tabular}


Table 6: Distribution of test results by education Level

\begin{tabular}{|c|c|c|c|c|c|c|c|}
\hline \multirow{2}{*}{\multicolumn{2}{|c|}{ Continuous attention }} & \multicolumn{6}{|c|}{ Education level } \\
\hline & & \multirow{2}{*}{$\frac{\text { Sec. School }}{5}$} & \multirow{2}{*}{$\frac{\text { High School }}{87}$} & \multirow{2}{*}{$\begin{array}{c}\text { University } \\
7\end{array}$} & \multirow{2}{*}{$\begin{array}{c}\text { Total } \\
99\end{array}$} & \multirow{2}{*}{$\frac{X^{2}}{4.15}$} & \multirow{2}{*}{$\frac{\mathbf{p}}{0.125}$} \\
\hline Adequate & Number & & & & & & \\
\hline & Percent. & 83.3 & 82.8 & 58.3 & 80.5 & & \\
\hline \multicolumn{8}{|c|}{ Selective attention } \\
\hline \multirow[t]{2}{*}{ Adequate } & Number & 6 & 99 & 12 & 117 & 1.08 & 0.582 \\
\hline & Percent. & 100.0 & 94.3 & 100.0 & 95.1 & & \\
\hline \multicolumn{8}{|c|}{ Reasoning test } \\
\hline \multirow[t]{2}{*}{ Adequate } & Number & 3 & 96 & 12 & 111 & 12.5 & 0.002 \\
\hline & Percent. & 50.0 & 91.4 & 100.0 & 90.2 & & \\
\hline \multicolumn{8}{|c|}{ Collision time test } \\
\hline \multirow[t]{2}{*}{ Adequate } & Number & 3 & 65 & 5 & 73 & 2.05 & 0.358 \\
\hline & Percent. & 50.0 & 61.9 & 41.7 & 59.3 & & \\
\hline
\end{tabular}

school graduates. Since there were no previous studies on this subject, it was not possible to compare it with similar study results. The importance of personnel selection systems, which ensure that the right personnel are reached and the appropriate persons are brought into the institution, is better understood every day. The basis of personnel selection systems that will allow the selection of the right personnel is to recognize and define the work correctly (14). Difficulties and hardship in social life are especially defined as problems. Problems usually consist of uncertainties, situations where accuracy and authenticity cannot be achieved and troubles and relationships with difficulties (15). In their study on private security guards, which is a dangerous and risky profession, Balli et al. suggested that the "extrovert" personality trait explains the perception of private security guards (in management positions) as leaders (16). In professions where interpersonal relationships are intense, placing a person suitable for work will keep possible problems at a minimal level.

\section{Limitations of the research}

The fact that the study was carried out only with security guards in a university and the compulsory use of some of the psychotechnical evaluations can be considered as limitations.

The results of this study showed that security guards were sufficiently successful in the attention, reasoning, and collision time prediction tests which were set as standard. In addition to assessing their psychological status when necessary, we believe that it would be useful to conduct a psychotechnical assessment prior to hiring those who work in critical tasks with intensive public interaction and communication (17).
Ethics Committee Approval: This study was approved by the Clinical Research Ethical Committee of the Istanbul University, Istanbul Faculty of Medicine (Date: 19.08.2019 No: 1026).

Informed Consent: Written consent was obtained from the participants.

Peer Review: Externally peer-reviewed.

Author Contributions: Conception/Design of Study- H.I., E.E., G.Ö.; Data Acquisition- H.I., E.E., N.Ş, Z.B.S., F.C.; Data Analysis/ Interpretation- E.H.I., G.Ö.; Drafting Manuscript- H.I., G.Ö., F.C.; Critical Revision of Manuscript- H.I., E.E., N.Ş., Z.B.S., G.Ö., F.C.; Final Approval and Accountability- H.I., E.E., N.Ş., Z.B.S., G.Ö., F.C.

Conflict of Interest: Authors declared no conflict of interest.

Financial Disclosure: Authors declared no financial support.

Etik Komite Onayı: Bu çalışma için etik komite onayı İstanbul Üniversitesi, İstanbul Tıp Fakültesi Klinik Araştırmalar Etik Kurulu'ndan alınmıştır (Tarih: 19.08.2019 No: 1026).

Bilgilendirilmiş Onam: Katılımcılardan bilgilendirilmiş onam alınmıştır.

Hakem Değerlendirmesi: Dış bağımsız.

Yazar Katkıları: Çalışma Konsepti/Tasarım- H.I., E.E., G.Ö.; Veri Toplama- H.I., E.E., N.Ş, Z.B.S., F.C.; Veri Analizi/Yorumlama- H.I., G.Ö.; Yazı Taslağı- H.İ., G.Ö., F.C.; İçeriğin Eleştirel İncelemesiH.I., E.E., N.Ş., Z.B.S., G.Ö., F.C.; Son Onay ve Sorumluluk- H.İ., E.E., N.Ş., Z.B.S., G.Ö., F.C.

Çıkar Çatışması: Yazarlar çıkar çatışması beyan etmemişlerdir.

Finansal Destek: Yazarlar finansal destek beyan etmemişlerdir. 


\section{REFERENCES}

1. Aras H. Özel güvenlik görevlilerinde kurumsal uzmanlaşma: bir model önerisi. Güvenlik Bilimleri Dergisi 2018;7(1):13158. [CrossRef]

2. Akbaş F, Dursun G, Ürün E. Özel güvenlik mesleğinin unvan sorunu ve gelişimi. Avrasya Sosyal ve Ekonomi Araştırmaları Dergisi (ASEAD) 2018;5(6):230-40.

3. Leino TM, Selin R, Summala H. Virtanen M. Violence and psychological distress among police officers and security guards. Occup Med 2011;61(6):400-6. [CrossRef]

4. Beech B, Leather P. Workplace violence in the health care sector: a review of staff training and integration of training evaluation models. Aggression Violent Behav 2006;11(1):2743. [CrossRef]

5. Akca N, Yılmaz A, ışık O. Sağlık çalışanlarına uygulanan şiddet: özel bir tıp merkezi örneği. Ankara Sağlık Hizmetleri Dergisi 2014;13(1):1-12. [CrossRef]

6. Oğuz V, Akyol KA. Problem çözme becerisi ölçeği (PÇBÖ) geçerlik ve güvenirlik çalışması. Çukurova Üniversitesi Eğitim Fakültesi Dergisi 2015;44(1):105-22. [CrossRef]

7. Soyer MK, Bilgin A. Problem solving skill perceptions of university students according to various variables. International Conference on New Trends in Education and Their Implications; 2010; November 11-13; Antalya, Türkiye: 2010.p.307-314.

8. Ekici DI, Balım AG. Ortaokul öğrencileri için problem çözme becerilerine yönelik algı ölçeği: geçerlilik ve güvenirlik çalışması. Yüzüncü Yıl Üniversitesi Eğitim Fakültesi Dergisi 2013;10(1):67-86.
9. Telman N, Türetgen iÖ, editors. Element selection. Istanbul: Epsilon Publishing; 2004.

10. ALG Psychotechnical Evaluation Tests. Available from: URL: https://www.algpsikoteknik.com/testler.html.

11. Akyıldız H, Kayalar M. İşletmelerin ruhsal tasarımında psikoteknik yöntemin transaksiyonel analiz ile boyutlandırılması. Uludağ Üniversitesi İktisadi ve İdari Bilimler Fakültesi Dergisi 2003;22(2):75-92.

12. Spor NY. Psikoteknik ve kullanım alanları. Mesleki Sağlık ve Güvenlik Dergisi(MSG) 2001; 2(5):13-6.

13. Tütüncü Ö, Tarlan D, Mamyrkulov N. Seyahat acentalarında çalışanların işe alma sürecini algılamaları ve İzmir ili örneği, Dokuz Eylül Üniversitesi Sosyal Bilimler Enstitüsü Dergisi 2003;5(1):113-40.

14. Gürer A. Psikoteknik yöntemin personel seçiminde uygulanması: Kit'ler üzerine bir alan araştırması. Uluslararası Sosyal Araştırmalar Dergisi 2017;10(51):1007-1020. [CrossRef]

15. Bagnall RJ. Lifelong education: the institutionalisation of an illiberal and regressive ideology? Educational Philosophy and Theory 1990; 22(1):1-7. [CrossRef]

16. Balli $E$. The effects of personality traits on being perceived as a leader: an empirical study in a private security officer sample. Anadolu University Journal of Social Sciences 2013;13(3):85-94.

17. İssever H, Onen L, Sabuncu HH, Altunkaynak O. Personality characteristics, psychological symptoms and anxiety levels of drivers in charge of urban transportation in Istanbul. Occupational Medicine 2002;52(6);297-303. [CrossRef] 